九州大学学術情報リポジトリ

Kyushu University Institutional Repository

\title{
Induction of Recessive Lethal Mutants by Dioxin and Dibenzofurans in Drosophila melanogaster
}

Kato, Kaori

Laboratory of Sericulture, Faculty of Agriculture, Kyushu University

Sakaguchi, Bungo

Laboratory of Sericulture, Faculty of Agriculture, Kyushu University

Nagayama, Junya

Laboratory of Public Health, School of Health Sciences, Kyushu University

Masuda, Yoshito

Dai ichi College of Pharmaceutical Sciences

他

https://doi.org/10.5109/23909

出版情報: 九州大学大学院農学研究院紀要. 34 (4)，pp.421-425，1990-03. Kyushu University バージョン：

権利関係 : 


\title{
Induction of Recessive Lethal $M$ utants by Dioxin and Dibenzofurans in Drosophila melanogaster
}

\author{
Kaori Kato*, Bungo Sakaguchi \\ J unya N agayama**, Y oshito $\mathrm{M}$ asuda*** and $\mathrm{K}$ atsumi $\mathrm{K}$ oga \\ Laboratory of Sericulture, Faculty of Agriculture, Kyushu \\ University, Fukuoka 812, Japan \\ (Received November 13, 1989)
}

\begin{abstract}
The mutagenicity of the polluting chemicals 2, 3, 7, 8-tetrachlorodibenzo- $p \cdot \operatorname{dioxin}, 2,3,4,7$, 8-pentachloro-dibenzofuran and 1, 2, 3, 4, 7, 8-hexachloro-dibenzofuran was tested by using Drosophila melanogaster. After wild type spermatogenic males were fed with the chemicals and mated to Muller-5 females, sex-linked recessive lethal mutations occurring on the $\mathrm{X}$ chromosome could be detected and new lines were established. However, the results bear the problem that the most frequent mutations were observed in the treatment at the stage of spermatogonia, rather than at the meiosis and maturation stages at which standard inheritable variation would be more frequently induced.
\end{abstract}

\section{INTRODUCTION}

Recent progress of chemical industries accompanies an accumulation of compounds that are scarcely degraded under the natural conditions. These stubborn residues include dioxins (polychlorinated dibenzo-p-dioxins, PCDDs) and polychlorinated dibenzofurans (PCDFs). PCDD and PCDF have many kinds of isomers, depending upon the number and position of chlorine atoms ; some of them are highly toxic to a certain animals in a species-specific manner (Masuda, 1987a ; Nishizumi, 1987 ; Masuda, 1988).

PCDDs and PCDFs not only occur as impurities of chlorine-containing industrial chemicals during production but also are easily produced by burning such substances during incineration, and thus have been widely spread in environments (Masuda, 1987a, b ; Kashimoto, 1987 ; Masuda, 1988 ; Safe, 1989).

The toxicity of PCDDs and PCDFs to animals have been studied in terms of lethality, malformation, fetal toxicity, induction of aryl hydrocarbon hydroxylase activities, effects on DNA and so on (Nagayama et al., 1985 ; Nagayama, 1987 ; Nishizumi, 1987 ; Denison et al., 1988 ;Cuthill and Poellinger, 1988 ; Wahba et al., 1988). However, whether or not these chemicals have inheritable effects is uncertain ; many conflicting results have been obtained for mutagenic potencies on mammalians

\footnotetext{
*Present address : Kagoshima Sericultural Experiment Station, Higashiichiki, Hioki-gun, Kagoshima $899-22$

**Laboratory of Public Health, School of Health Sciences, Kyushu University, Katakasu, Higashiku, Fukuoka 812

***Daiichi College of Pharmaceutical Sciences, Fukuoka 815, Japan
} 
and other organisms including Drosophila melanogaster (Zimmering et al., 1985 ; Giri, 1986 ; Safe, 1989). In view of the well-known advantages of D.melanogaster as an experimental material for genetics, we have tried to extend the investigation with this species. In the present study the spermatogenic male adults of D. melanogaster are treated with the chemicals to detect mutagenic potencies.

\section{MATERIALS AND METHODS}

As chemicals 2, 3, 7, 8-tetrachlorodibenzo-p-dioxin (TCDD), 2, 3, 4, 7, 8pentachloro-dibenzofuran (PCDF) and 1, 2, 3, 4, 7, 8-hexachloro-dibenzofuran (HCDF) were chosen. TCDD is a typical PCDD and known for its high lethality to the guinea pig, comparable to that of tetrodotoxin (cf. Masuda, 1987a). The other two are PCDFs. All were synthesized as described previously (Kuroki et al., 1980). Their purity was more than $99 \%$ in terms of gas chromatography/mass spectrometry. These were dissolved in olive oil at a concentration of $40 \mu \mathrm{g} / \mathrm{ml}$.

The Muller-5 strain of D.melanogaster was used as a detector for recessive, sex-linked mutants (Spencer and Stern, 1948) : The X-chromosome of the strain possessed $w^{\text {a }}$ (white apricot) and $B$ (Bar) as markers. This chromosome also has an inversion to prevent crossing-over. Wild type males of the Oregon- $\mathrm{R}$ strain one day after emergence were injected with the olive oil solution of the test chemical via a thin needle of glass capillary. Alternatively, the male flies were fasted for $24 \mathrm{hr}$ and then reared for $24 \mathrm{hr}$ with a diet made of honey plus yeast that was mixed with the olive oil solution of the chemical. The treated males were mated with Muller-5 females according to the schedule described in RESULTS and DISCUSSION. Then the $F_{1}$ progenies were sib-mated. When males with normal phenotype could not be found in the $\mathrm{F}_{2}$, there would be a lethal mutant on the $\mathrm{X}$-chromosome and the $B$ females in the $\mathrm{F}_{2}$ were crossed with the $B w^{\mathrm{a}}$ males to establish a mutant line. The survival rate of treated flies and their $F_{1}$ was more than $95 \%$, not different from the control given the vehicle olive oil. All procedures were made at $22^{\circ} \mathrm{C}$.

\section{RESULTS AND DISCUSSION}

Male Oregon-R flies were treated with TCDD, PCDF of HCDF and surveyed for the detection of the recessive, lethal mutants occurring on the $\mathrm{X}$-chromosome by crossing with Muller-5 females. The first mating was begun on day 0 , shortly after the treatment. The mated females were collected and replaced by new females on day 3 and then on day 6 . The progenies obtained after these 3 types of mating were named, in that order, broods A, B and C. It takes about 9 days that sperm mature from the stem cells (Lindsley and Tokuyasu, 1980). Therefore, the approximate spermatogenetic stages at which the chemical caused effects could be assumed : the stage of sperm maturation for brood A, the stage of meiosis for brood B and the stage of somatic mitoses of the spermatogonia for brood C.

As shown in Table 1, injection of the chemicals to the flies gave one mutant, whereas oral administration produced 11 mutants. Thus the feeding method gave more marked results than the injection method. Previously, both injection and feeding of TCDD gave no lethal mutants (Zimmering et al., 1985). In the present study, the dose 
Table 1. Induction of mutations by TCDD, PCDF and HCDF."

\begin{tabular}{llccccc}
\multirow{2}{*}{$\begin{array}{c}\text { Mode of } \\
\text { administration }\end{array}$} & Chemical & \multicolumn{7}{c}{ Brood $^{\mathrm{b}}$} \\
\cline { 3 - 7 } & & $\mathrm{A}$ & $\mathrm{B}$ & $\mathrm{C}$ & Total & $\%$ \\
\hline \multirow{2}{*}{ Injection } & TCDD & $0 / 65$ & $0 / 192$ & $1 / 104$ & $1 / 361$ & 0.28 \\
& PCDF & $0 / 44$ & $0 / 158$ & $0 / 77$ & $0 / 279$ & 0.00 \\
& HCDF & $0 / 70$ & $0 / 117$ & $0 / 25$ & $0 / 172$ & 0.00 \\
& Control & $0 / 79$ & $0 / 161$ & $0 / 45$ & $0 / 285$ & 0.00 \\
\hline \multirow{2}{*}{ Ingestion } & TCDD & $3 / 413$ & $0 / 642$ & $0 / 361$ & $3 / 1,416$ & 0.21 \\
& PCDF & $0 / 454$ & $0 / 500$ & $1 / 321$ & $1 / 1,275$ & 0.08 \\
& HCDF & $0 / 488$ & $0 / 570$ & $6 / 554$ & $8 / 1,612$ & 0.50 \\
& Control & $0 / 418$ & $0 / 532$ & $2 / 341$ & $2 / 1,291$ & 0.15 \\
\hline
\end{tabular}

${ }^{a}$ Data were given by the number of mutants per that of the $F_{1}$ pair assessed.

${ }^{\circ}$ Broods were obtained by pairing on days 0 to 3,3 to 6 and 6 to 9 , respectively, after administration of the chemical to males. Thus broods $\mathrm{A}, \mathrm{B}$ and $\mathrm{C}$ referred to as treatments at the spermatogenic stages of maturation, meiosis and spermatogonia, respectively.

Control flies received the solvent olive oil.

by injection was technically the maximum $(0.2 \mu$ l of the above olive oil solution per individual fly). As to the oral administration, on the other hand, $25 \mu \mathrm{l}$ of the test solution was introduced per one rearing bottle and mingled with the diet by which several male flies were reared, and thus the net ingested amount was unknown.

Brood $\mathrm{C}$ exhibited more clear-cut mutation rates than broods $\mathrm{A}$ and $\mathrm{B}$. It should be noted here that the individuals of brood $\mathrm{C}$ may have received disturbance at the stage of spermatogonia as stated above. Generally the spermatogonial stage is more insensitive to mutagenic treatments than the other spermatogenesis stages probably because of the high repair capacity and elimination of cells during multiplication of spermatogonia (e. g. Yoshikawa et al., 1984 ; Shima and Shimada, 1988). Therefore, a group of mutants in brood $\mathrm{C}$ obtained here are assumed to be of a cluster that formed as a clone of a mutant spermatogonium.

The mutation rate for the control in the ingestion experiment $(0.16 \%)$ will seem to be extremely high at first glance. However, this value is reasonable in case of $D$. melanogaster without any precaution to depress spontaneous mutations because of transposable elements (cf., e. g. Yoshikawa et al., 1984). At present, the percentages smaller than 0.16 were obtained for the PCDF-ingested flies and for most of the injected animals including the control. We infer that some unexpected conditions, e. g. selective survival of healthy individuals, might have disturbed the investigation system.

In spite of the above compromise, the mutants detected here could be established as lines. Formerly D.melanogaster was reported to be insensitive to TCDD in terms of mutagenesis (Zimmering et al., 1985) as well as of the potency of inducing aryl hydrocarbon hydroxylases (Bigelow et al., 1985 ; Hällström, 1986). In the present results a group of mutations were produced by $\mathrm{HCDF}$ (particularly in brood C), and also the potencies of TCDD and PCDF could not be ruled out, although the mutation rates seemed to be low if any. We are trying to increase further the dose of oral administration to the flies. Observation of developmental abnormality in $D$. melanogaster to detect primary effects of the chemicals, and application of the somatic 
mutation test devised for $D$. melanogaster to detect genotoxic activity without rearing progenies (Graf et al., 1984) ' are also under way in our laboratory and the results will be published elsewhere.

\section{ACKNOWLEDGEMENTS}

We thank Dr. C. Kiyohara of the Department of Public Health, Faculty of Medicine, Kyushu University, for advice and help about the treatment of chemicals. This study was supported by a Grant-in-Aid for Scientific Research on Priority Areas (No. 62602015) from the Ministry of Education, Science and Culture of Japan.

\section{REFERENCES}

Bigelow, S. W., J. A. Zijlstra, E. W. Vogel and D. W. Nebert 1985 Measurements of the cytosolic Ah receptor among four strains of Drosophila melanogaster. Arch. Toxicol., $56: 219-225$

Cuthill, S. and L. Poellinger 1988 DNA binding properties of dioxin receptors in wild-type and mutant mouse hepatoma cells. Biochemistry, 27 : 2978-2982

Denison, M. S., J. M. Fisher and J. P. Whitlock, Jr. 1988 Inducible, receptor-dependent proteinDNA interaction at a dioxin-responsive transcriptional enhancer. Proc.Natl.Acad. Sci. USA, 85 : 2528-2532

Giri, A. K. 1986 Mutagenic and genotoxic effects of 2, 3,7, 8-tetrachlorodibenzo-p-dioxin, a review. Mutation Res., $168:$ : 241-248

Graf, U., F. E. Wurgler, A. J. Katz, H. Frei, H. Juon, C. B. Hall and P. G. Kale 1984 Somatic mutation and recombination test in Drosophila melanogaster. Environ. Mutagenesis, $6: 153-188$

Hällström, I. 1986 Effects of pretreatment with 2, 3, 7, 8-tetrachlorodibenzofuran on microsomal monooxygenase activity in Drosophila melanogaster. Mutation Res., 174 : $93-97$

Kashimoto, T. 1987 Environmental levels of chlorinated dioxins and related compounds. Toxicology Forum, $10:$ :556-565

Kuroki, H., K. Haraguchi and Y. Masuda 1980 Synthesis of polychlorinated dibenzofuran isomers and their gas chromatographic profiles. Chemosphere, $13: 561-573$

Lindsley, D. L. and K. T. Tokuyasu 1980 Spermatogenesis. In "The Genetics and Biology of Drosophila", ed. by M. Ashburner and T. R. F. Wright, Academic Press, New York, pp. 225-294

Masuda, Y. 1987a Dioxins : toxicity, pollution and human effect. Toxicology Forum, 10 : 553-555

Masuda, Y. 1987b Polychlorinated dibenzo-p-dioxin and related compound pollution in human tissues. Toxicology Forum, $10: 566-574$

Masuda, Y. 1988 Environmental pollution of polychlorinated dibenzo-p-dioxins and dibenzofurans. Eisei Kagaku, 34: 197-209

Nagayama J. 1987 AHH inducibility of dioxins and dibenzofurans and possible mechanisms of their toxicity. Toxicology Forum, $10: 591-600$

Nagayama, J., H. Kuroki, Y. Masuda, S. Handa and M. Kuratsune 1985 Genetically mediated induction of aryl hydrocarbon hydroxylase activity in mice by polychlorinated dibenzofuran isomers and 2, 3, 7, 8-tetrachlorodibenzo-p-dioxin. Arch. Toxicol., 56 : 226-229

Nishizumi, M. 1987 Toxicity of dioxins in laboratory animals. Toxicology Forum, 10: 575-582

Safe, S. 1989 Polychlorinated biphenyls (PCBs): mutagenicity and carcinogenicity. Mutation Res., 220: $31-47$

Shima, A. and A. Shimada 1988 Induction of mutations in males of the fish Oryziaslatipes at a specific locus after y-irradiation. Mutation Res., 198 : 93-98

Spencer, W. P. and C. Stem 1948 Experiments to test the validity of the linear R-dose mutation frequency relation in Drosophila at low dosage. Genetics, $33: 43-74$ 
Yoshikawa, I., T. Ayaki and K. Oshima 1984 Comparative studies of dose-response curves for recessive lethal mutations induced by ethylnitrosourea in spermatogonia and in spermatozoa of Drosophila melanogaster. Environ. M utagen., 6 : 489-496

Wahba, Z. Z., T. A. Lawson and S. J. Stohs 1988 Induction of hepatic DNA single strand breaks in rats by 2, 3, 7, 8-tetrachlorodibenzo-p-dioxin (TCDD). Cancer Lett., 29: 281-286

Zimmering, S., J. M. Mason, R. Valencia and R. C. Woodruff 1985 Chemical mutagenesis testing in Drosophila. II. Results of 20 coded compounds tested for the national toxicology program. Environ. Mutagen., $7: 87-100$ 